\title{
PERFORMANCE SIMULATION OF SEMI-TRANSPARENT PHOTOVOLTAIC GLASS ON A SKYLIGHT FOR COMMERCIAL BUILDING
}

\author{
SIMULAÇÃO DE DESEMPENHO DE VIDRO FOTOVOLTAICO SEMITRANSPARENTE EM \\ ABERTURA ZENITAL PARA EDIFÍCIO COMERCIAL
}

\author{
Leno Pôrto Dutra ${ }^{1}$ \\ (D) Isabel Tourinho Salamoni ${ }^{2}$ \\ (D) Eduardo Grala da Cunha ${ }^{3}$ \\ ${ }^{1}$ Companhia Estadual de Distribuição de \\ Energia Elétrica, Divisão de Serviços de \\ Rede, Pelotas, RS, Brasil, \\ leno.dutra@hotmail.com \\ 2 Universidade Federal de Pelotas, Pelotas, \\ RS, Brasil, isabel.salamoni@ufpel.edu.br \\ 3 Universidade Federal de Pelotas, Pelotas, \\ RS, Brasil, eduardo.grala@ufpel.edu.br
}

Contribuição dos autores:

LPD: investigação, metodologia, escrita rascunho original, escrita - revisão e edição. ITS: conceituação, análise formal, metodologia, supervisão, validação, visualização, escrita - revisão e edição. EGC: conceituação, análise formal, metodologia, administraç̃ão do projeto, supervisão, validação, visualização, escrita - revisão e edição.

Fomento: Não houve fomento

Declaração de conflito: nada foi declarado

Editor Responsável:

Letícia de Oliveira Neves (i)

\begin{abstract}
The demand for energy in buildings is a worldwide research subject due to its importance in the global electric load share. Besides, photovoltaic conversion to generate electricity locally is one of the ways to meet that demand. This work aims to evaluate the application of semi-transparent photovoltaic glass on a skylight of a commercial building and estimate electricity consumption and production using computational simulation with EnergyPlus. The opening size was set as a variable parameter. Its performance was compared to an ordinary skylight and opaque modules under the same conditions for three different Brazilian bioclimatic zones. Results show that the area's change provided significant differences in generation and less important ones in consumption. Among the bioclimatic zones, the building presented the lowest consumption and the highest generation for all configurations in the coldest zone, making it the best region for net electricity, i.e., purchased from a utility. Comparing semi-transparent with opaque modules, the latter produced much more energy, but consumption was reduced by an average of $28 \%$ in favour of the photovoltaic glass. The main conclusion is that the use of photovoltaic technology in a semi-transparent glass is promising regarding the integration of generators to the building, but the efficiency rates need to increase to bring it closer to opaque modules in performance.
\end{abstract}

Keywords: Photovoltaic solar energy. Semi-transparent photovoltaic modules. Computational simulation. EnergyPlus.

\section{Resumo}

A demanda por energia em edifícios é um tema de pesquisa mundial, devido ao seu peso relativo no total da carga elétrica. Além disso, o uso da conversão fotovoltaica para gerar eletricidade no próprio local de consumo é uma das maneiras de atender a essa demanda. Este trabalho tem como objetivo avaliar a aplicação de vidro fotovoltaico semitransparente em abertura zenital de um edifício comercial e estimar o consumo e a produção de eletricidade usando simulação computacional com o EnergyPlus. O tamanho da abertura foi modificado e seu desempenho foi comparado com uma abertura comum e o uso de módulos opacos nas mesmas condições, em três diferentes zonas bioclimáticas brasileiras. Os resultados mostram que a mudança na área proporcionou diferenças significativas na geração e menos importantes no consumo. Dentre as zonas bioclimáticas, na mais fria o edifício apresentou o menor consumo e a maior geração para todas as configurações, tornando-a a melhor região para atendimento a uma meta de eletricidade líquida, ou seja, adquirida da rede pública. Comparando módulos semitransparentes com opacos, estes últimos produziram mais energia, mas o consumo foi reduzido em média $28 \%$, com vantagem para o vidro fotovoltaico. Conclui-se que o uso da tecnologia fotovoltaica em vidro semitransparente é promissor para a integração de geradores ao edifício, mas precisa aumentar o rendimento para se aproximar dos módulos opacos no desempenho.

Palavras-chave: Energia solar fotovoltaica. Módulos fotovoltaicos semitransparentes. Simulação computacional. EnergyPlus.

How to cite this article:

DUTRA, L. P.; SALAMONI, I. T.; CUNHA, E. G. da. Performance simulation of semi-transparent photovoltaic glass on a skylight for commercial building. PARC Pesquisa em Arquitetura e Construção, Campinas, SP, v. 12, p. e021009, 2021. DOI: http://dx.doi.org/10.20396/parc.v12i00.8657973 


\section{Introduction}

Residential, commercial, and governmental buildings are responsible for $50.5 \%$ of the electricity consumption and $14.8 \%$ of the consumption of all types of energy in Brazil (EMPRESA DE PESQUISA ENERGÉTICA, 2019). Due to social and economic development, energy demand in Brazil is increasing and requiring correspondent infrastructure. Currently, renewable energy sources make $41.8 \%$ of the national energy mix (EMPRESA DE PESQUISA ENERGÉTICA, 2019), a high figure compared to $18.1 \%$ of the world average (REN21, 2019). As solar radiation availability in Brazil surpasses countries with much more installed power of this kind, there is a vast growth potential of this source in the country. The city of Florianópolis, which has one of Brazil's lowest radiation rates, has $20 \%$ more sunlight than Germany's sunniest region (DIDONÉ, 2014). Photovoltaic (PV) generation is, therefore, a reasonable alternative source to apply to Brazilian buildings. Opaque modules applied on roofs are the predominant type, but there is room for more options. This work aims to analyse electricity consumption and generation through semi-transparent photovoltaic (STPV) glass on the skylight of a hypothetical commercial building. Moreover, the influence of variation of the STPV glass area was verified by comparing the energy and thermal performance of this system with an ordinary skylight - equipped with safety glass - and also with a whole opaque roof covered with PV modules for three Brazilian bioclimatic zones (ASSOCIAÇÃO BRASILEIRA DE NORMAS TÉCNICAS, 2005a). The region under study is the South of the country, for its heating/cooling loads, whereas buildings in the rest of the country need quite exclusively to be cooled. The climatic complexity of these three zones justifies the choice in order to maximise research results.

Few studies are testing STPV in skylights. So, the effect of solar radiation in such a range of angles, both for ambient heating and PV generation, was considered a gap to be investigated. The authors intend to contribute to the PV body of knowledge through an experiment based on simulation, analysis, and performance comparison amongst the studied options. Parameters from a literature review are employed to configure the models, as described in detail in the Method section.

Unless where clearly identified, the word 'consumption' means 'electricity consumption' and the word 'generation' means 'electricity generation' along with this text.

\section{Theory}

\section{PV glass}

The PV component can be used both in roofs and façades and may have opaque or semitransparent surfaces with structural function, sun protection, and coating. When composing the building, it is considered an integrated system or building integrated photovoltaic (BIPV). Jelle (2016) describes the BIPV generation as a system that replaces the building envelope, acting as a climate interface and electricity source, saving material and working time, besides reducing energy costs. As an essential component of contact between the interior and exterior of buildings, windows have many functions, such as allowing daylight, ventilation, and visual access to the outside. However, due to their poor performance as insulators, a large amount of heat is transferred through them, resulting in a considerable increase in air conditioning demand. Therefore, the development of new types of energy-efficient windows is an urgent task for researchers. STPV glasses are a solution that can provide daylighting and electricity generation simultaneously (WANG et al., 2016). Li et al. (2009) compared the STPV glass with tinted glass. They concluded that the latter allows penetration of more 
solar radiation in the room, increasing the demand for air conditioning and reducing the lighting load without generating electricity. The authors carried out a case study comparing these options' performance, with and without dimming control. The PV glasses models were used only in the southwest façade, while the others remained with tinted glass. Results indicated that compared to the base case - tinted glasses without lighting control, the use of STPV windows in the southwest façade resulted in an annual saving of $1.6 \%$, together with a reduction in air conditioning consumption and own generation. Combined with lighting control, the global saving was $12 \%$, in addition to gains in reducing peak demand and emissions of greenhouse gases and other pollutants into the atmosphere (LI et al., 2009).

\section{Computer simulation and the Sandia Model}

PV solar generation may be calculated with solar radiation data from solarimetric maps or through computer simulation software. However, most of the programs dedicated to simulating PV generation are limited to estimating energy production, not solving the simulated building's energy consumption. EnergyPlus (US DEPARTMENT OF ENERGY, 2019a) may be used to analyse thermal energy in buildings. It can also evaluate energy generation through surfaces that convert solar radiation into electrical energy, simulating a solar PV generation. To estimate power output from the PV modules, EnergyPlus presents three different configuration methods. The Simple method requires, as input data, only a fixed or scheduled value for module conversion efficiency. The Equivalent One-diode Model requires the current and voltage of the PV module. As a result, it obtains a PV panel's operational performance given by the radiation and cell operating temperature. The third method is Sandia Photovoltaic Array Performance Model (SAPM), developed by Sandia National Laboratory, which uses coefficient equations based on actual measurements and experimental tests. This method presents greater complexity in its configuration since it requests several input data referring to the PV module model's characteristic curve under study (US DEPARTMENT OF ENERGY, 2019b). Only a few academic papers used SAPM. Custódio and Rüther (2017) carried out a study to evaluate how PV integration to a residential building influences internal temperature and energy consumption. A building was modelled with three different PV integration cases, and the data of the rooms' temperature and energy consumption were evaluated with EnergyPlus. The energy generation was estimated through a daily PV generation equation and by the Sandia model in EnergyPlus. Results showed that, in the worst case, EnergyPlus simulation estimated $6 \%$ more electricity generated than the PV generation equation method. The difference was considered small, so the EnergyPlus computational simulation method was validated to compare energy generation and consumption of the building.

Wang et al. (2016) conducted an experimental study to validate the Sandia model in EnergyPlus. The test was carried out at the Polytechnic University of Hong Kong from October 2012 to February 2013. The experiment included measurements and records of optical, thermal, and electrical parameters and a meteorological station. Validation was performed using the statistical method recommended by ASHRAE. The validated model was used as a basis for simulating different window configurations in order to compare their energy performance. In all cases, the net energy used by the model was calculated by adding consumption for heating, cooling, and lighting and subtracting the energy generated by the PV modules applied.

STPV in skylight

Wong et al. (2008) simulated a semi-transparent opening in a living room ceiling of a typical Japanese residence. For the heating period, the hours of the day with the highest 
heat gain through the opening coincide with the room's occupancy, resulting in thermal comfort with minimum energy consumption for heating. At night the heat loss through this opening was comparable to the total energy loss through the house's windows. Hence, the demand for heating at night and the beginning of the day was greater than the alternative without the ceiling's opening. During the cooling period, the heat gain through the opening caused more consumption. In the annual balance, the energy savings provided by the opaque BIPV generator system were higher by $7.5 \%, 5.6 \%$, and $6.4 \%$, respectively, compared to Low-E, STPV20, and STPV 50 openings. The simulation considered Osaka's climate, where the heating and cooling periods occur, respectively, from November 29th to March 25th and from June 27th to September 17th.

Considering the great potential of this issue for application in Brazil and the scarce bibliography available, a study is proposed to analyse the integration of these PV generators on the roofs of buildings using STPV glasses employing a computer simulation model with EnergyPlus.

\section{Method}

This work uses computational simulation with EnergyPlus as a strategy to solve the research problem. The method is organised into four steps. In the first, a literature review was carried out on the topics: STPV modules and simulation of PV systems in EnergyPlus using SAPM. In the second step, the base case was modelled in SketchUp (TRIMBLE NAVIGATION LIMITED, 2016) with the Euclid plug-in (BIG LADDER SOFTWARE, 2017). In the third step, computational simulations were configured, including the solar PV system's parameters composed of semi-transparent glasses or opaque modules, alternately. In the fourth stage, the computational simulations were performed, and the results were analysed.

\section{Building modelling for computational simulation}

The hypothetical building was modelled in SketchUp with the Euclid plug-in. The model under study is a detached building of $336 \mathrm{~m}^{2}$ and a ceiling height of $3 \mathrm{~m}$ that represents an office building and has seven rooms, one of which is endowed with a skylight. Each room is a thermal zone. The corridor has two doors at its ends, and the other thermal zones have one inner door and one external window each, except the one with skylight, with no window or door. This zone's dimensions are $12 \mathrm{~m} \times 6 \mathrm{~m}$. The total window-towall ratio is $17.11 \%$, with partials of $33.33 \%$ to the North and $20.83 \%$ to the South. There are no glass panes to the East or West. Surroundings were not taken into consideration to prevent shading interference in the results. Figure 1 depicts the modelling of the building with the two different skylight areas analysed, which are also the same areas and positions of the opaque module arrangements, in the models without a skylight.
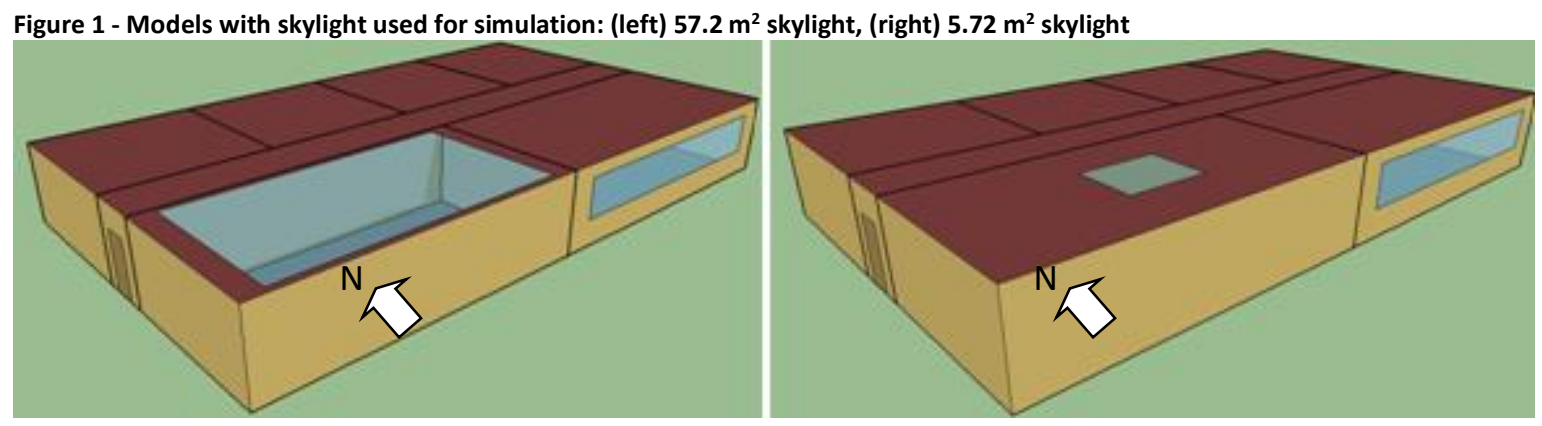

Source: the authors. 
DUTRA, L. P.; SALAMONI, I. T.; CUNHA, E. G. da.

Performance simulation of semi-transparent photovoltaic glass on a skylight for commercial building

\section{Weather file}

To perform the simulations for the different bioclimatic zones, weather files for Curitiba were used to represent $B Z 1$, Pelotas to represent $B Z 2$ and Porto Alegre to represent $B Z 3$ (LABORATÓRIO DE EFICIÊNCIA ENERGÉTICA EM EDIFICAÇÕES, 2012). Figure 2 is a map of Brazil with the location of the three cities highlighted. Figure 3 is a graph with mean temperatures at extreme seasons for the chosen locations.

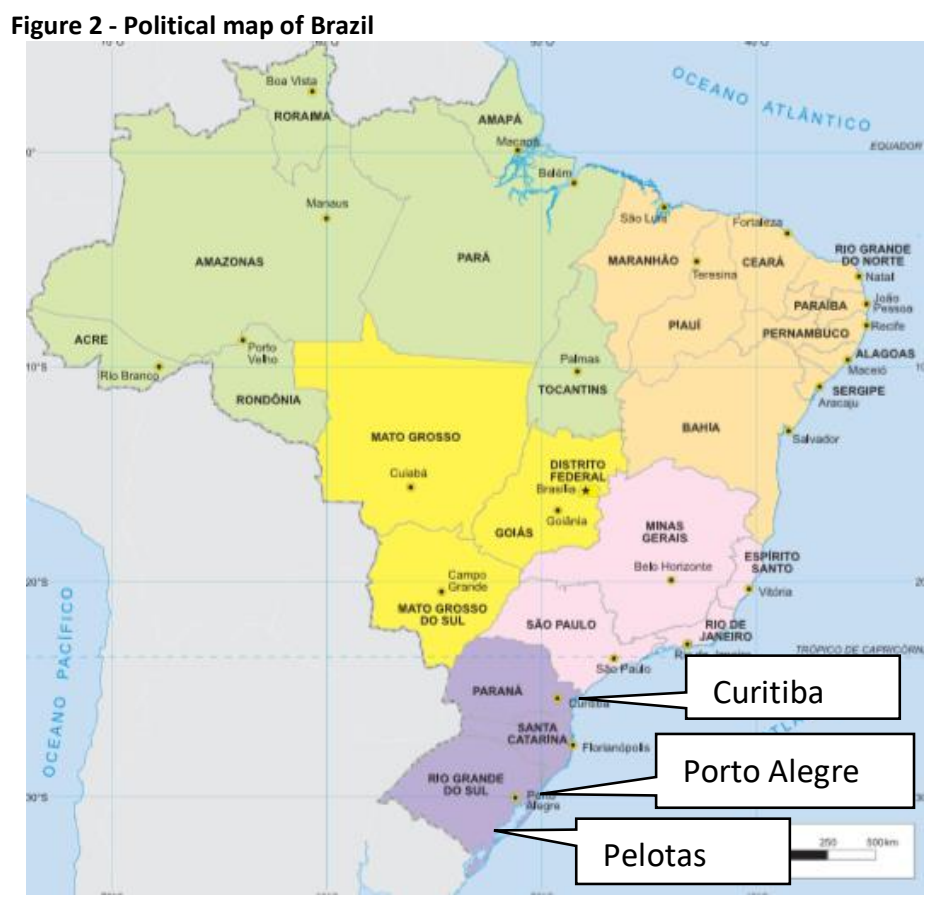

Source: adapted from Instituto Brasileiro de Geografia e Estatística (2019).

Figure 3 - Exterior mean temperatures

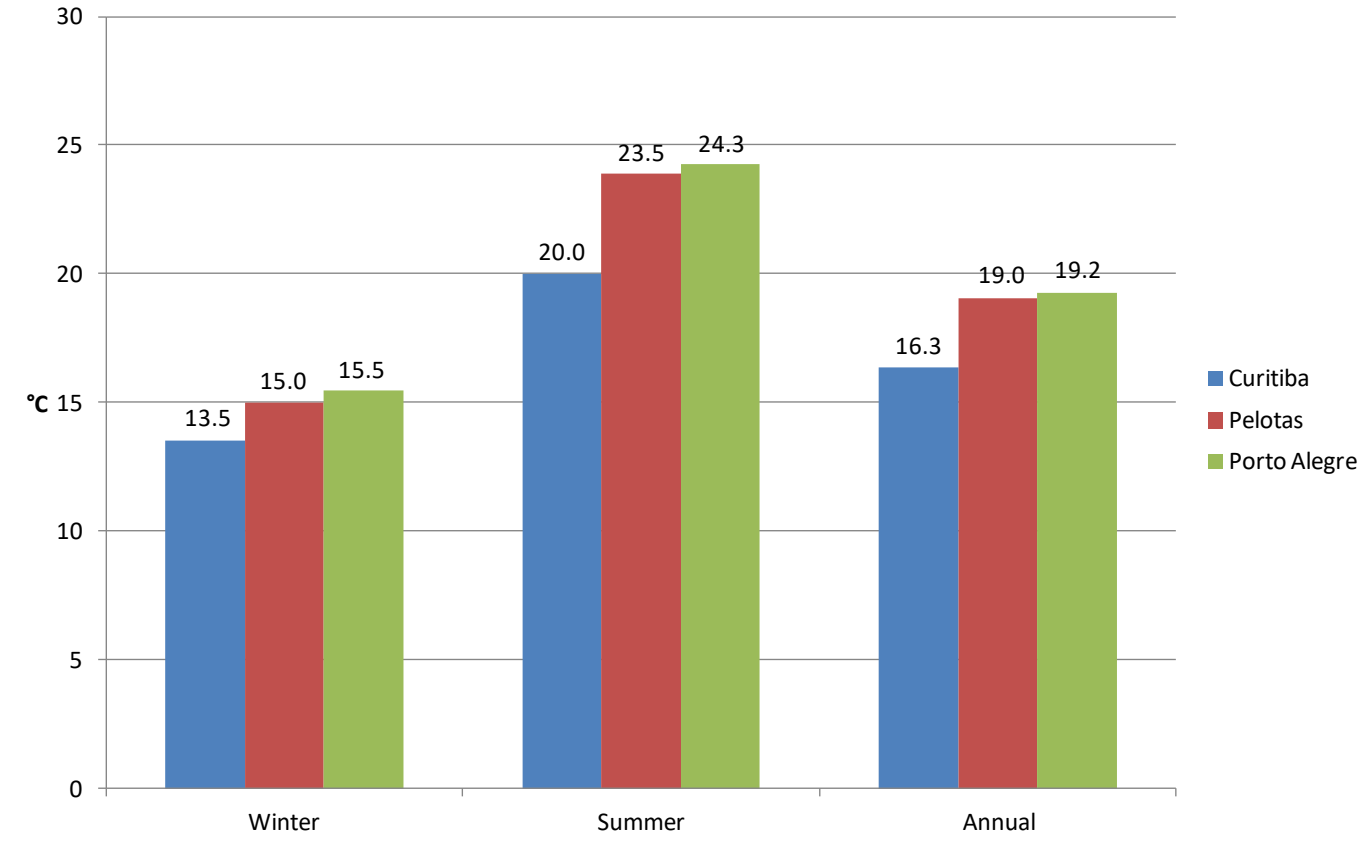

Source: the authors. 


\section{Simulated cases}

Table 1 shows the variable parameters in the simulations performed for the three bioclimatic zones under study. The scenarios correspond to the combination of all the parameters. The model was configured in EnergyPlus version 9.1.0.

Table 1 - Variable parameters

\begin{tabular}{cccc}
\hline \multirow{2}{*}{ Bioclimatic Zone } & \multicolumn{3}{c}{ Area $\left(\mathrm{m}^{2}\right)$} \\
\cline { 2 - 4 } & STPV & IG without PV & Opaque PV \\
\hline \multirow{2}{*}{1} & 5.72 & 5.72 & 5.72 \\
\cline { 2 - 4 } & 57.2 & 57.2 & 57.2 \\
\hline \multirow{2}{*}{2} & 5.72 & 5.72 & 5.72 \\
\cline { 2 - 4 } & 57.2 & 57.2 & 57.2 \\
\hline \multirow{2}{*}{3} & 5.72 & 5.72 & 5.72 \\
\hline
\end{tabular}

Notes: STPV: Semi-transparent photovoltaic; IG: Insulated glass. Source: the authors.

\section{Use and occupancy}

As this research only considers consumption in the hall, a room with short-time and intermittent occupancy, its use was disregarded for purposes of producing heat dissipated by people (ASSOCIAÇÃO BRASILEIRA DE NORMAS TÉCNICAS, 2008a).

\section{Lighting System Settings}

The RTQ-C ${ }^{(1)}$ method was used as a reference to configure the lighting power density for the entire building area, observing the ' $A$ ' energy efficiency level. For offices, the rate was set as $9.7 \mathrm{~W} / \mathrm{m}^{2}$ (INSTITUTO NACIONAL DE METROLOGIA, NORMALIZAÇÃO E QUALIDADE INDUSTRIAL, 2012). The lighting system was available from 9 am to $6 \mathrm{pm}$ on working days.

An artificial light intensity control (dimmer) was configured in the zone with a skylight through the Daylighting: Controls field of EnergyPlus. A continuous sensor was located in the centre of the room, at a height equal to the work plane $(0.75 \mathrm{~m})$. A lighting setpoint of 500 lux (ASSOCIAÇÃO BRASILEIRA DE NORMAS TÉCNICAS, 2013) was used, with a minimum input power of $30 \%$ and the corresponding minimum light output at $20 \%$, the EnergyPlus default sets.

\section{Opaque surfaces settings}

Table 2 shows the composition of the building's external surfaces of the study, considering perforated bricks. The external heterogeneous walls were configured using the equivalent wall method (ORDENES et al., 2003).

\begin{tabular}{|c|c|c|c|c|}
\hline Externa surface & Material & $\begin{array}{l}\text { Thickness } \\
\text { (m) }\end{array}$ & $\begin{array}{c}\text { Thermal } \\
\text { transmittance } \\
-\mathrm{U} \\
\mathrm{W} /\left(\mathrm{m}^{2} . \mathrm{K}\right)\end{array}$ & $\begin{array}{c}\text { Thermal capacity - TC } \\
\left(\mathrm{kJ} / \mathrm{m}^{2} \mathrm{~K}\right)\end{array}$ \\
\hline \multirow{5}{*}{ External walls } & Plaster & 0.025 & \multirow{5}{*}{2.49} & \multirow{5}{*}{186} \\
\hline & Brick's ceramic & 0.0253 & & \\
\hline & Brick's air & $>0.05$ & & \\
\hline & Brick's ceramic & 0.0253 & & \\
\hline & Plaster & 0.02 & & \\
\hline \multirow{3}{*}{ Roof } & Ceramic tile & 0.02 & \multirow{3}{*}{$(2)$} & \multirow{3}{*}{ (3) } \\
\hline & Air & $>0.05$ & & \\
\hline & Concrete & 0.15 & & \\
\hline
\end{tabular}




\section{Transparent glazing settings}

The windows were configured with data obtained from the International Glazing Database (IGDB), accessed by the authors through WINDOW 7.7 (BERKELEY LAB, 2019), two ordinary glass panes of $3 \mathrm{~mm}$ each, separated by a $12 \mathrm{~mm}$ air chamber.

For the STPV settings, the parameters are those proposed by Wang et al. (2016), except for the tempered inner glass that was replaced by laminated glass. It was due to the horizontal position, to which only safety glasses are accept (ASSOCIAÇÃO BRASILEIRA DE NORMAS TÉCNICAS, 2016). Figure 4 is a schematic diagram of the module composition.

Figure 4 - Composition of the STPV skylight

Outer side

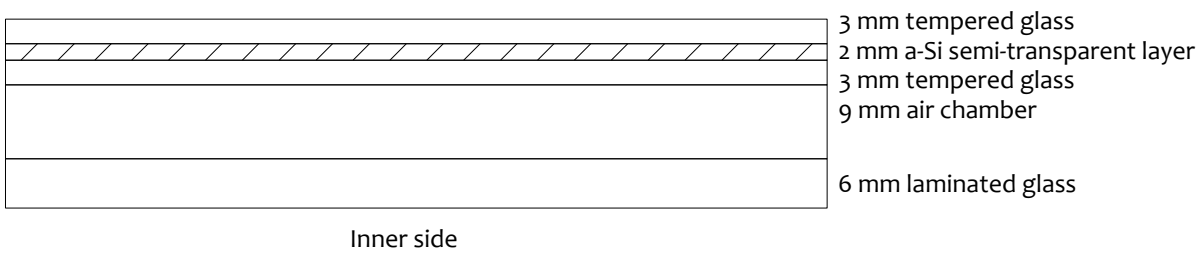

Source: adapted from Wang et al. (2016)

The ordinary glass layers were configured with data obtained from IGDB. The $3 \mathrm{~mm}$ glass outer pane has a dirt correction factor for visible and solar transmittance of 0.7 for the horizontal slope in a non-industrial zone (US DEPARTMENT OF ENERGY, 2019b). The laminated glass used as the inner layer is the Clear laminate $(2.3 \mathrm{~mm}+.030$ "PVB $+2.3 \mathrm{~mm})$, from ID 3068 on the National Fenestration Rating Council (NFRC). This layer's parameters were obtained from OPTICS 6.0 (BERKELEY LAB, 2013). The air chamber was represented by a thermal resistance of $0.15 \mathrm{~m}^{2} . \mathrm{K} / \mathrm{W}$ (ASSOCIAÇÃO BRASILEIRA DE NORMAS TÉCNICAS, 2005b), considering the descending heat flow as the predominant direction. The STPV layer's parameters (WANG et al., 2016) are listed in Table 3.

Table 3 - STPV glass parameters

\begin{tabular}{cc}
\hline Parameters & Values \\
\hline Thickness & $0.002 \mathrm{~m}$ \\
\hline Solar Transmittance at Normal Incidence & 0.213 \\
\hline Front Side Solar Reflectance at Normal Incidence & 0.115 \\
\hline Back Side Solar Reflectance at Normal Incidence & 0.115 \\
\hline Visible Transmittance at Normal Incidence & 0.07 \\
\hline Front Side Visible Reflectance at Normal Incidence & 0.079 \\
\hline Back Side Visible Reflectance at Normal Incidence & 0.079 \\
\hline Infrared Transmittance at Normal Incidence & 0 \\
\hline Front Side Infrared Hemispherical Emissivity & 0.853 \\
\hline Back Side Infrared Hemispherical Emissivity & 0.834 \\
\hline Conductivity & $0.486 \mathrm{~W} /(\mathrm{m} . \mathrm{K})$ \\
\hline
\end{tabular}

Source: adapted from Berkeley Lab (2013), Associação Brasileira de Normas Técnicas (2005b) and Wang et al. (2016)

An insulated glass (IG) was configured in the models with skylight without PV cells, consisting of a laminate inner and a tempered outer pane, of $6 \mathrm{~mm}$ thickness each, separated by airspace of $9 \mathrm{~mm}$, thus the same configuration of the STPV's, except for the a-Si layer.

\section{HVAC}

A direct expansion system was adopted, configured in HVAC:TemplateZone:PTHP object in EnergyPlus. The availability schedule was set from 8 am to $6 \mathrm{pm}$ on working days. The temperature setpoints were $21^{\circ} \mathrm{C}$ for heating and $26^{\circ} \mathrm{C}$ for cooling, according respectively to the winter lower and summer higher limits given by Brazilian standard 
DUTRA, L. P.; SALAMONI, I. T.; CUNHA, E. G. da.

Performance simulation of semi-transparent photovoltaic glass on a skylight for commercial building

NBR 16401 (ASSOCIAÇÃO BRASILEIRA DE NORMAS TÉCNICAS, 2008b). The system's coefficient of performance (COP) for both was set at 3.24 W/W to achieve an ' $A$ ' grade for the efficiency label (INSTITUTO NACIONAL DE METROLOGIA, NORMALIZAÇÃO E QUALIDADE INDUSTRIAL, 2013).

\section{Ground temperature settings}

Ground temperature was configured using Slab tool in EnergyPlus. The monthly average results are showed in Table 4.

Table 4 - Mean ground temperatures for the model in three bioclimatic zones (BZ)

\begin{tabular}{cccccccccccccc}
\hline & \multicolumn{10}{c}{ Temperature } \\
& Jan & Feb & Mar & Apr & May & Jun & Jul & Aug & Sep & Oct & Nov & Dec \\
\hline BZ1 & 29 & 29 & 27 & 24 & 20 & 18 & 16 & 19 & 21 & 21 & 25 & 26 \\
\hline BZ2 & 30 & 28 & 27 & 24 & 19 & 16 & 17 & 17 & 19 & 23 & 26 & 28 \\
\hline BZ3 & 34 & 34 & 32 & 27 & 19 & 17 & 22 & 24 & 24 & 26 & 31 & 33 \\
\hline Source: the authors.
\end{tabular}

\section{PV modules performance}

The parameters of SAPM components adopted in this work were obtained through a literature review. For the STPV glass, data resulted from measurements suggested by Peng et al. (2015). For the opaque modules, the BP Solar model SX3200 was used due to the area dimension's similarity concerning the STPV module. Table 5 lists the values applied to the electrical parameters grouped by type.

Table 5 - Electrical parameters

\begin{tabular}{ccc}
\hline Parameters & STPV & Opaque \\
\hline Number of cells in series (Ns) & 160 & 50 \\
\hline Number of cells in parallel (Np) & 1 & 1 \\
\hline Short circuit current (Isc) & $1.04 \mathrm{~A}$ & $8.7 \mathrm{~A}$ \\
\hline Open circuit voltage (Voc) & $139.2 \mathrm{~V}$ & $30.8 \mathrm{~V}$ \\
\hline Current at the maximum power point (Imp) & $0.86 \mathrm{~A}$ & $8.16 \mathrm{~A}$ \\
\hline Voltage at the maximum power point (Vmp) & $102.5 \mathrm{~V}$ & $24.5 \mathrm{~V}$ \\
\hline Diode factor (n) & 2.432 & 1.319 \\
\hline Current at 0.5 Voc (IxO) & $0.97 \mathrm{~A}$ & $8.59 \mathrm{~A}$ \\
\hline Current at 0.5 (Vmp+Voc) (Ixx0) & $0.55 \mathrm{~A}$ & 5.71 \\
\hline
\end{tabular}

Source: System Advisor Model database (NATIONAL RENEWABLE ENERGY LABORATORY, 2014), Peng et al. (2015) and Peng (2018)

The last two parameters showed in Table 5 for the STPV module were obtained through the graph personally provided by the author Jinqing Peng (PENG, 2018) and reproduced in Figure 5 .

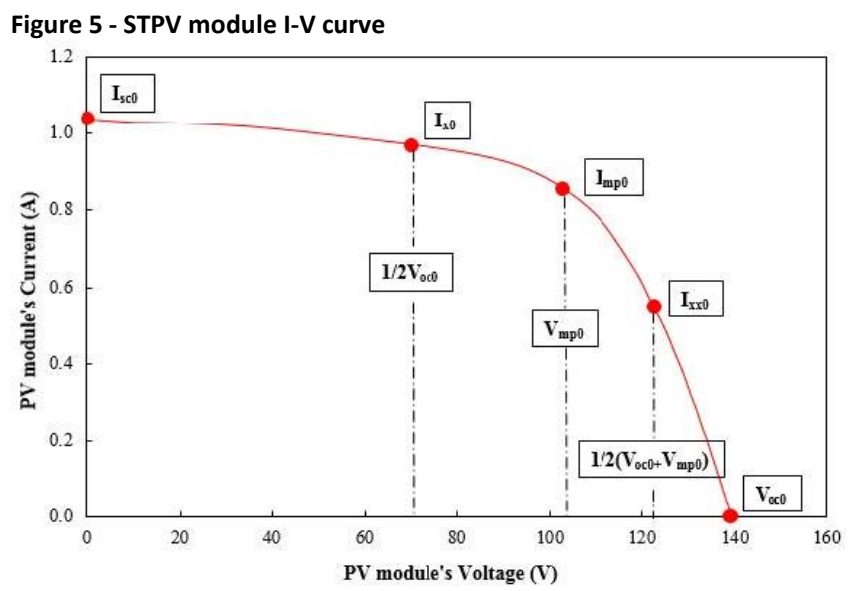

Source: Peng (2018). 
DUTRA, L. P.; SALAMONI, I. T.; CUNHA, E. G. da.

Performance simulation of semi-transparent photovoltaic glass on a skylight for commercial building

Table 6 lists the temperature coefficients used in simulations (KING; BOYSON; KRATOCHVIL, 2004; NATIONAL RENEWABLE ENERGY LABORATORY, 2014; PENG et al., 2015), divided by 100 to convert from $\%{ }^{\circ} \mathrm{C}$ to ${ }^{\circ} \mathrm{C}^{-1}$, in order to meet EnergyPlus units.

Table 6 - Temperature coefficients

\begin{tabular}{|c|c|c|}
\hline Parameters & STPV & Opaque \\
\hline Normalised temperature coefficient for Isc ( $\alpha \mid s c)$ & $0.0006^{\circ} \mathrm{C}-1$ & $0.00065^{\circ} \mathrm{C}-1$ \\
\hline Normalised temperature coefficient for Imp ( $\alpha \operatorname{lmp})$ & $-0.00281^{\circ} \mathrm{C}-1$ & $-0.0002^{\circ} \mathrm{C}-1$ \\
\hline Temperature coefficient for module open circuit voltage at reference conditions ( $\beta$ Voc0) & -0.4769 V. ${ }^{\circ} \mathrm{C}-1$ & -0.111 V. ${ }^{\circ} \mathrm{C}-1$ \\
\hline Coefficient for irradiance dependence of open circuit voltage (m $\beta$ Voc) & 0 & 0 \\
\hline Temperature coefficient for module maximum-power-voltage at reference conditions ( $\beta \mathrm{Vmp} 0)$ & -0.2476 V. ${ }^{\circ} \mathrm{C}-1$ & -0.114 V. ${ }^{\circ} \mathrm{C}-1$ \\
\hline Coefficient for irradiance dependence of maximum power voltage (mßVmp) & 0 & 0 \\
\hline Empirical coefficient relating module temperature at low wind and high solar irradiance (a) & -3.311 & -3.537 \\
\hline Empirical coefficient relating module temperature decrease with increasing wind speed (b) & -0.02289 & -0.0721 \\
\hline
\end{tabular}

Source: King, Boyson and Kratochvil (2004), System Advisor Model database (NATIONAL RENEWABLE ENERGY LABORATORY, 2014) and Peng et al. (2015).

Table 7 shows polynomial function factors that correct the impact of solar spectrum on the modules short circuit current.

Table 7 - Coefficients of the spectral correction function

\begin{tabular}{ccc}
\hline Parameters & STPV & Opaque \\
\hline $\mathrm{a} 0$ & 0.9410 & 0.9415 \\
\hline $\mathrm{a} 1$ & 0.1328 & 0.052728 \\
\hline $\mathrm{a} 2$ & -0.0968 & -0.0095876 \\
\hline $\mathrm{a} 3$ & 0.0197 & 0.00067629 \\
\hline $\mathrm{a} 4$ & -0.0016 & -0.000018111
\end{tabular}

Source: System Advisor Model database (NATIONAL RENEWABLE ENERGY LABORATORY, 2014) and Peng et al. (2015).

Table 8 shows the coefficients that multiply the effective solar irradiance to obtain current and voltage at the maximum power point and the currents at the other two points of the I-V curve, all as a function of the module operating temperature.

Table 8 - Radiance coefficients

\begin{tabular}{ccc}
\hline Table 8 - Radiance coefficients & & Opaque \\
\hline Parameters & STPV & 1.0015 \\
\hline c0 & 0.9708 & -0.0015 \\
\hline c1 & 0.0335 & 0.12669 \\
\hline c2 & -0.1255 & -6.05171 \\
\hline c3 & -4.4458 & 0.9842 \\
\hline c4 5 & 1.0296 & 0.0158 \\
\hline c6 & 0.0001 & 1.1442 \\
\hline c7 & 1.2320 & -0.1442
\end{tabular}

Source: System Advisor Model database (NATIONAL RENEWABLE ENERGY LABORATORY, 2014) and Peng et al. (2015).

Table 9 shows the polynomial function factors that define the influence of the solar incident angle on the short circuit current.

Table 9 - Coefficients of the solar incident angle function

\begin{tabular}{ccc}
\hline Parameters & STPV & Opaque \\
\hline b0 & 1 & 1 \\
\hline b1 & -0.002438 & -0.002438 \\
\hline b2 & 0.0003103 & 0.0003103 \\
\hline b3 & -0.00001246 & -0.00001246 \\
\hline b4 & 0.000000211 & 0.000000211 \\
\hline b5 & -0.00000000136 & -0.00000000136
\end{tabular}

Source: System Advisor Model database (NATIONAL RENEWABLE ENERGY LABORATORY, 2014).

Table 10 shows the other model parameters. For the STPV model, the unitary value for $\mathrm{fd}$ is due to the modules' flat shape and the high transmission of light through the front surface (HANSEN et al., 2014). 
Table 10 - Other parameters

\begin{tabular}{ccc} 
Parameters & STPV & Opaque \\
\hline Thermal voltage $[\delta(\mathrm{Tc})]$ & 0 & $3{ }^{\circ} \mathrm{C}$ \\
\hline Fraction of diffuse irradiance used by module $(\mathrm{fd})$ & 1 & 1 \\
\hline
\end{tabular}

Source: King; Boyson; Kratochvil (2004) and System Advisor Model database (NATIONAL RENEWABLE ENERGY LABORATORY, 2014).

\section{Inverter}

The model adopted for the inverter was Simple because this research's scope is restricted to the STPV modules' performance. Hence, the constant efficiency of this model allows an unbiased analysis, regardless of the inverter characteristics.

\section{Reference model settings}

The simulations were performed with a variety of scenarios, as shown in Table 1. The skylight dimensions were chosen so that one scenario has an area ten times larger than the other. Thus, performance differences because of this variable become noticeable. The module used in the performance parameters reference work has $1.3 \mathrm{~m} \times 1.1 \mathrm{~m}$ (WANG et al., 2016). To match the studied room's dimensions, the large and small areas tested are, respectively, composed of $40(8 \times 5)$ modules with a total area of $57.2 \mathrm{~m}^{2}$ and $4(2 \times 2)$ modules with a total area of $5.72 \mathrm{~m}^{2}$. These variations were input through the following fields:

- Number of Modules in Series, in Generator:Photovoltaic group (40 or 4 modules).

- Coordinates of the skylight vertices, in FenestrationSurface:Detailed group.

\section{Output settings}

The simulation results were first grouped by bioclimatic zone in order to systematise analysis. Afterward, they were gathered by type of load, comparing performances in the three bioclimatic zones, considering the variation of the opening area with and without PV generation and opaque models. The output data were related to the consumption of heating, cooling, and lighting for the studied room, in addition to the energy produced by the PV generator.

\section{Results and discussion}

\section{Bioclimatic Zone 1}

For BZ1, the most remarkable difference in consumption occurred for the cooling load. The opaque and the STPV models with smaller skylight areas (both with nearly the same cooling consumption) were $66 \%$ and $84 \%$ lower than the models with larger skylight areas, respectively STPV and IG. The differences were $46 \%$ and $59 \%$, respectively, for the STPV and IG models with larger areas, making the opposite comparisons for the heating load. These results indicate that, proportionally, the heat gain through the skylight on hot days in this region was higher than the heat loss on cold days. In absolute figures, the heating consumption exceeded three times the cooling consumption in the models with a smaller opening area. Nevertheless, when the skylight took up almost the entire ceiling, the cooling consumption became four times larger than the heating consumption for the IG model. However, BZ1 is the coldest region in the country. These results show the importance of the greenhouse effect in buildings with large glazing areas.

Also notable is the difference in air-conditioning consumption between the STPV and the IG models. The transparent glass required twice the energy for cooling, whereas the semi-transparent one demanded $32 \%$ more energy for heating. The comparative results 
considering transparency were generally consistent with the variation of the opening area, i.e., the greater the area and/or the greater the transparency, the higher the cooling consumption and the lower the heating consumption. The exception occurred for the smaller skylight area, where the IG model showed slightly higher heating consumption than the STPV model.

The lighting consumption also showed a wide variation between scenarios. The highest consumption occurred for the opaque models, as expected. Comparing them to the STPV and IG models, both with the larger opening area, the consumption was $63 \%$ and $69 \%$ higher due to the dimming difference. For the same reason, the smaller opening area models had a consumption of $39 \%$ and $68 \%$ lower than the opaque models. As expected, the higher transparency of the IG model resulted in a lower lighting consumption. It should be noted that the illuminance measurement was performed through a single sensor in the middle of the room, right below the centre of the skylight, in both models (larger or smaller skylight areas). Therefore, the lighting consumption was almost identical for the IG models, even for such different areas. If sensors were placed at other points in the room, the variation would be diverse.

The total estimated consumption for the models in BZ1 varied up to $46 \%$, following the lighting loads, which resulted predominantly in the models adopted. The exception to this profile occurred in the IG model with a larger area. It is the only case in which cooling consumption exceeded lighting consumption for this bioclimatic zone.

Generation exceeded consumption in the models with the largest number of modules, whereas the energy generated for the smaller options was insufficient. While the models of 40 STPV and opaque modules generated a surplus of respectively 3,308 $\mathrm{kWh} /$ year and 9,267 kWh/year, the 4-module models showed positive net consumption of $1,135 \mathrm{kWh} /$ year and $1,048 \mathrm{kWh} /$ year, respectively, for the STPV and opaque scenarios. Comparing the 40-module opaque and STPV models results, the case with opaque modules (despite its higher consumption) produced a higher surplus due to the generation 2.5 times higher than the STPV one.

Figure 6 depicts, in absolute figures, the results just described.

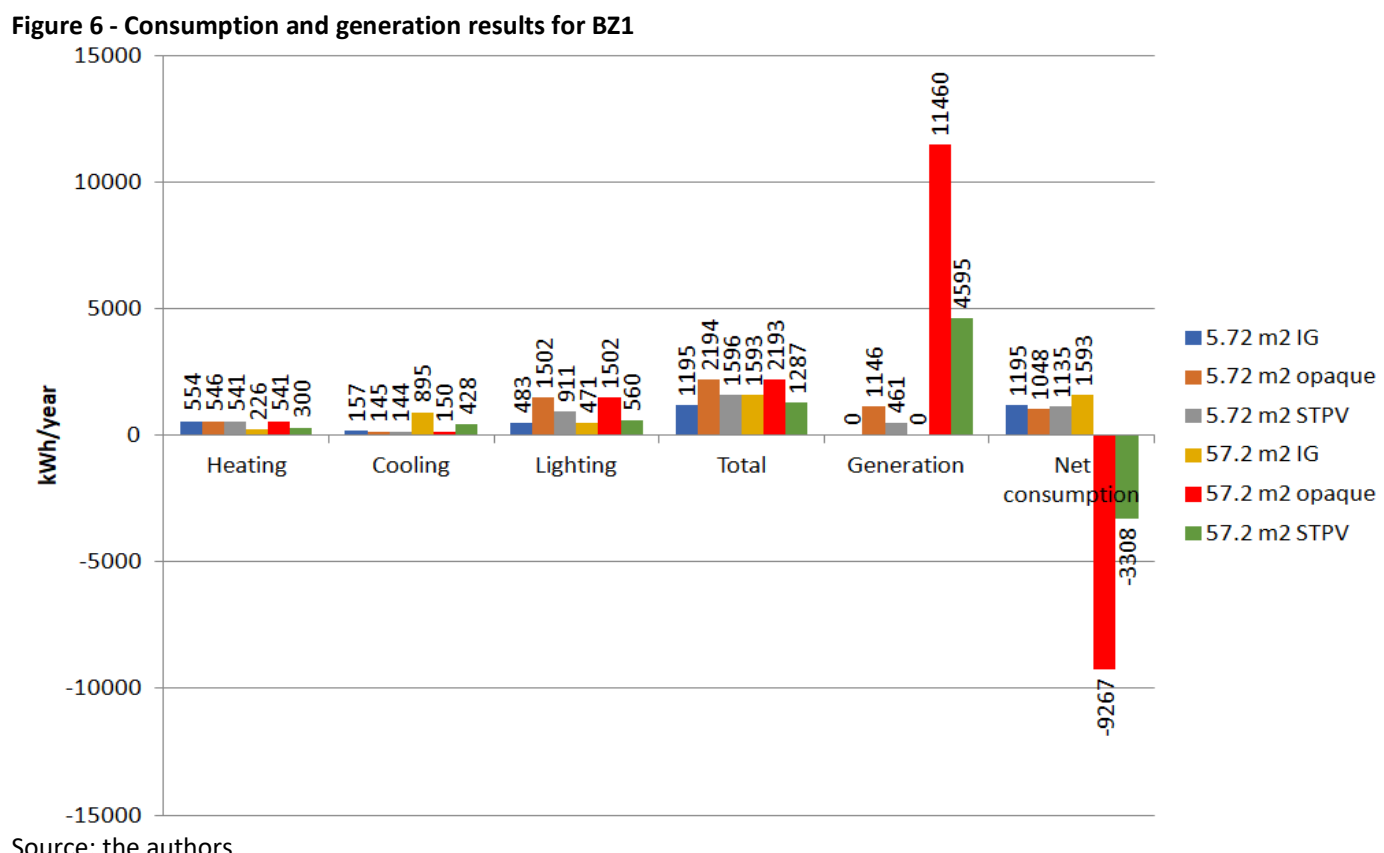




\section{Bioclimatic Zone 2}

In BZ2, the cooling load variation was also more significant than heating, being $54 \%$ smaller in the opaque and small opening model, compared to the STPV and large opening model, and $75 \%$ smaller compared to the IG and large opening model. Like in $\mathrm{BZ} 1$, the heating consumption was increased by the reduction or elimination of the opening, also in a smaller proportion than the cooling. The lighting consumption varied in the same way as BZ1, but in BZ2, the difference between the STPV and the opaque models was slightly lower. Considering that the consumption in both opaque models (large and small skylight areas) was the same for all bioclimatic zones - due to the lack of windows in the analysed room, this smaller relative difference was correlated to lighting absolute consumption in BZ2.

Like in BZ1, lighting loads predominated, apart from the same exception of BZ1, which is the cooling load in the IG model with a larger skylight area.

The surplus generation for the models with larger skylight area and the positive net consumption for the models with smaller skylight area had the same behaviour as in BZ1 and the comparison between the surplus of the STPV and the opaque models. In cases with generation and larger skylight area, the difference in surplus energy reached $40 \%$, with an advantage for BZ1, due to the lower production and higher consumption of BZ2.

The results described in this item, in absolute figures, can be seen in Figure 7.

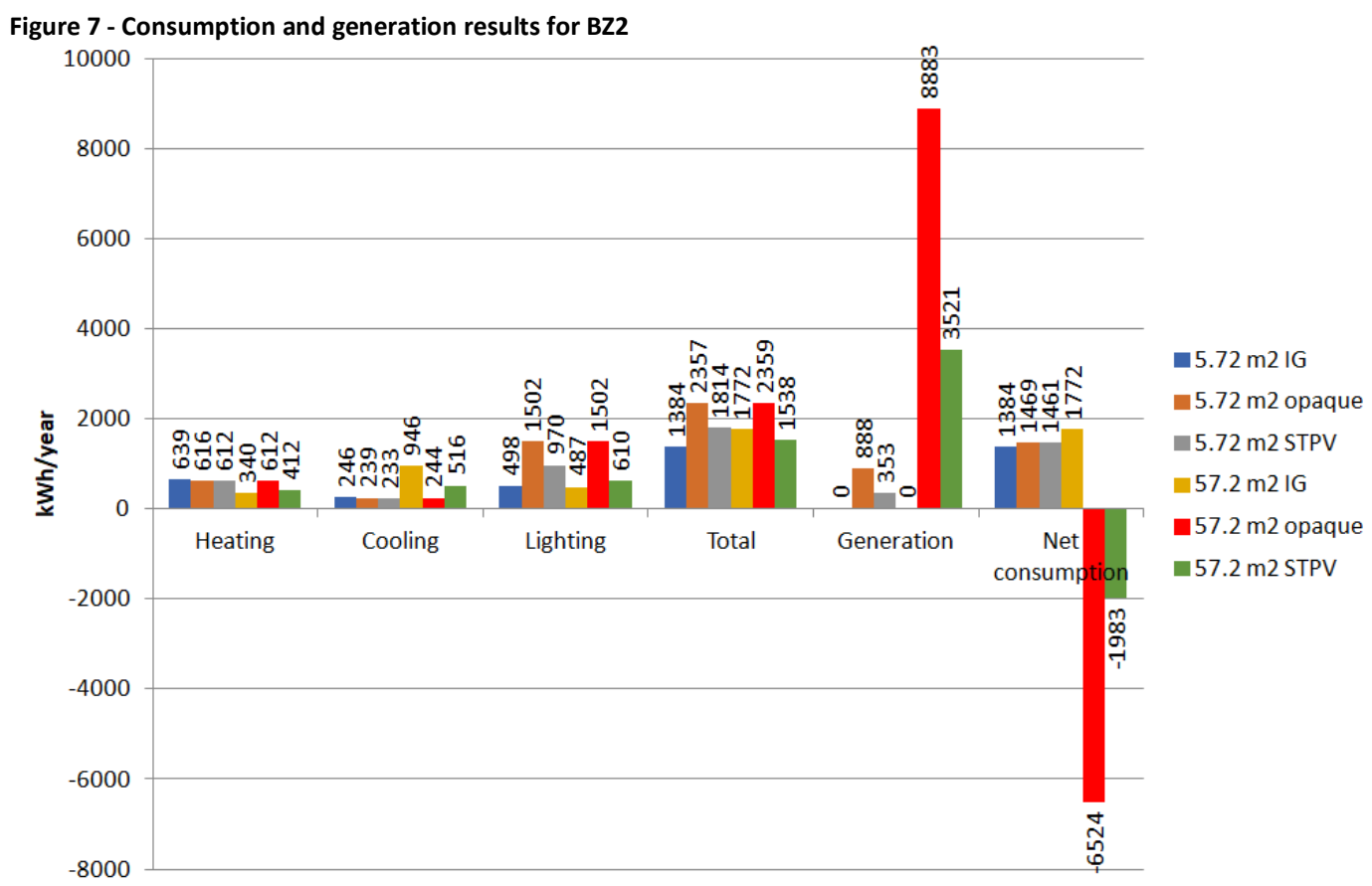

Source: the authors.

\section{Bioclimatic Zone 3}

The air-conditioning consumption variation in BZ3 was similar to the other bioclimatic zones, except for a smaller difference between the cooling loads' models. This result shows that this bioclimatic zone, due to its higher average temperature compared to the others, demands a higher cooling load and requires a differentiated strategy to avoid excessive heat gains. With the same constructive characteristics of the other zones, the replacement of transparent to opaque surfaces had less expressive results than in BZ1 and BZ2. 
The results show the importance of the cooling loads in BZ3 due to their higher absolute values, which surpass the heating loads in all scenarios. Proportionally, the comparative results of surplus generation and net consumption followed the pattern already examined for the other bioclimatic zones.

Figure 8 shows, in absolute figures, the results just described.

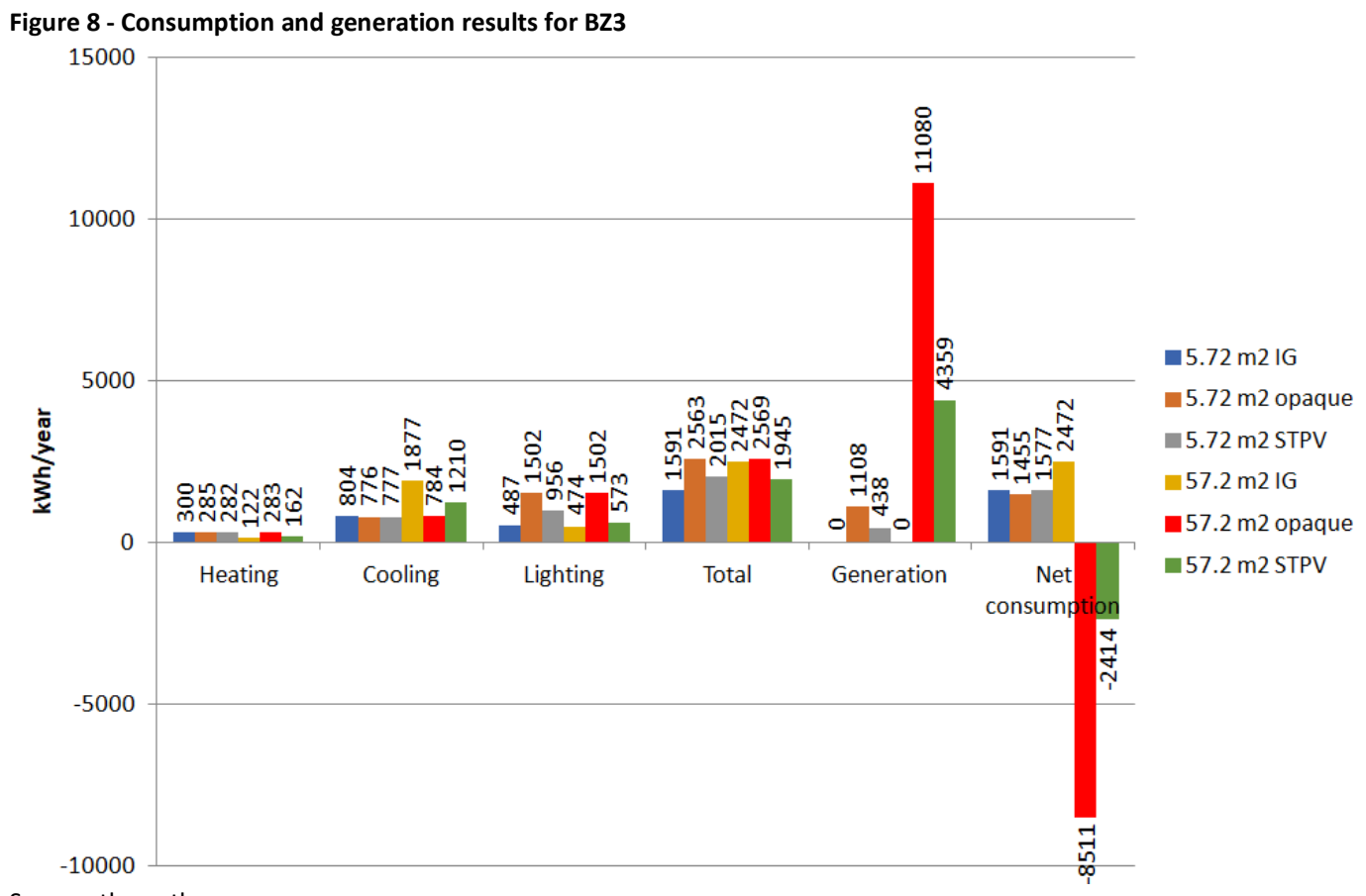

\section{Comparison between bioclimatic zones}

The model with the highest heating consumption was the IG model with a larger skylight area in BZ2, as indicated in Figure 9. This result disagrees with each bioclimatic zone's climatic conditions since the lower average temperatures occur in BZ1, as indicated in Figure 4. Nevertheless, the heating consumption was higher in BZ2 than in BZ1 for all simulated models, with the most significant relative difference occurring for the IC model with a larger skylight area, even though it had the lowest absolute consumption to its higher heat gain and the greenhouse effect. BZ3 had a lower heating consumption compared to the other two bioclimatic zones, as expected.

Results for cooling consumption were consistent between bioclimatic zones, agreeing with their average temperatures. Figure 10 shows these results.

Lighting consumption varied less than $5 \%$ between the bioclimatic zones for all models with openings. This result shows that this end-use was not significantly impacted by the differences between the three analysed cities. Dimmed lighting showed differences in consumption for the models with semi-transparent opening, as confirmed in Figure 11. Even small openings, such as the 4-module ones, had a high consumption difference compared to the total absence of daylight (opaque models). The difference was due to the direct exposure of the luxmeter to the sunlight, since it was positioned under the centre of the skylight. The transparent opening and the high sunlight penetration into the room made the bioclimatic zone and the opening area not differ from the results. 
DUTRA, L. P.; SALAMONI, I. T.; CUNHA, E. G. da.

Performance simulation of semi-transparent photovoltaic glass on a skylight for commercial building

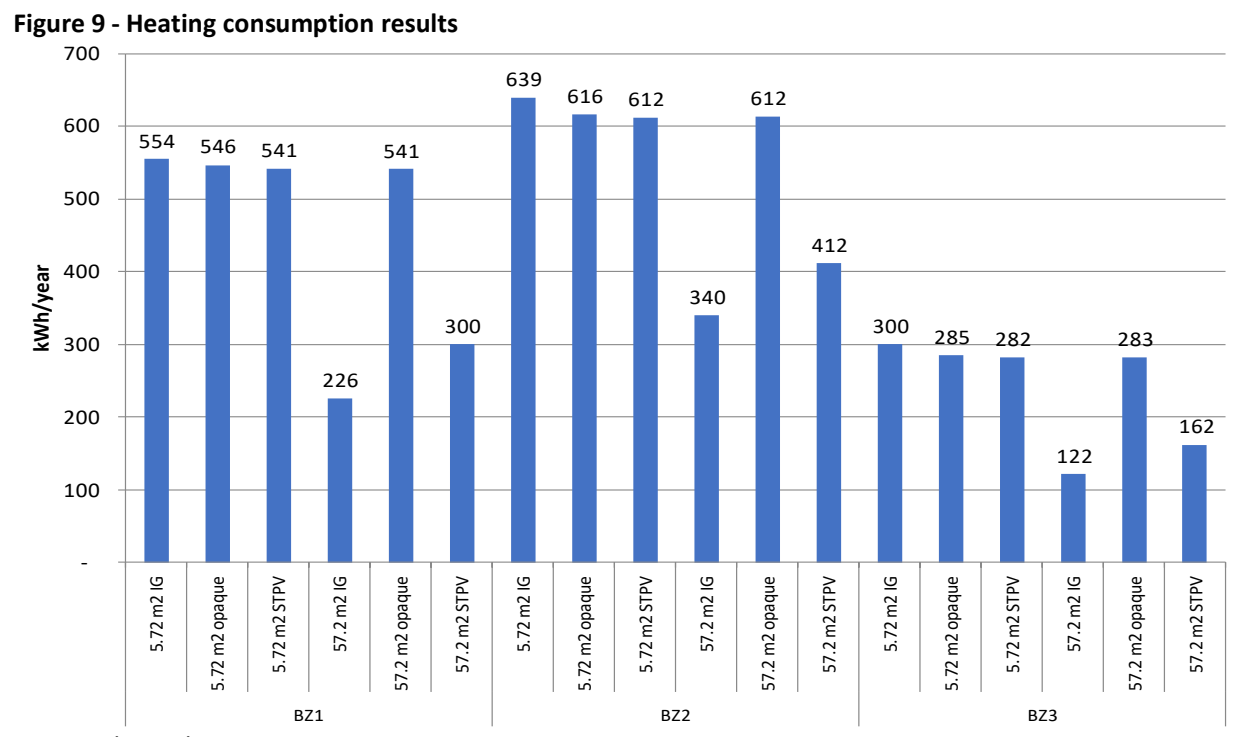

Source: the authors

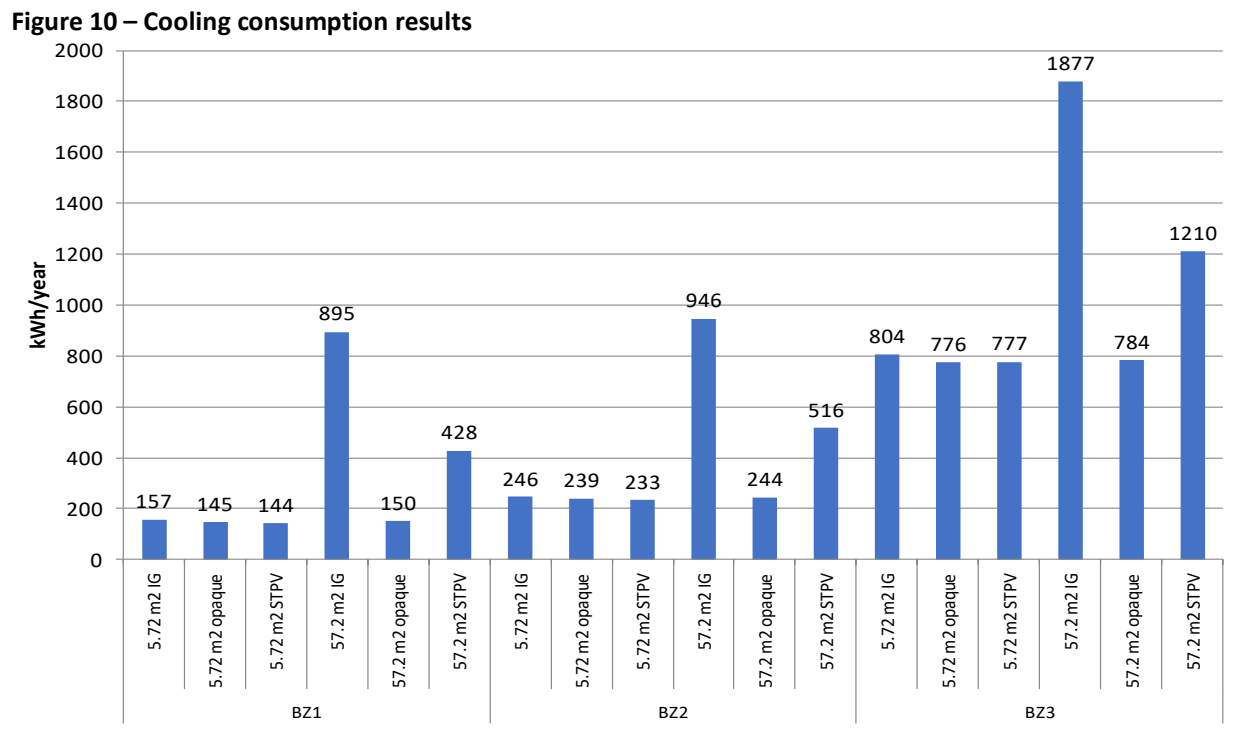

Source: the authors

Figure 11 - Lighting consumption results

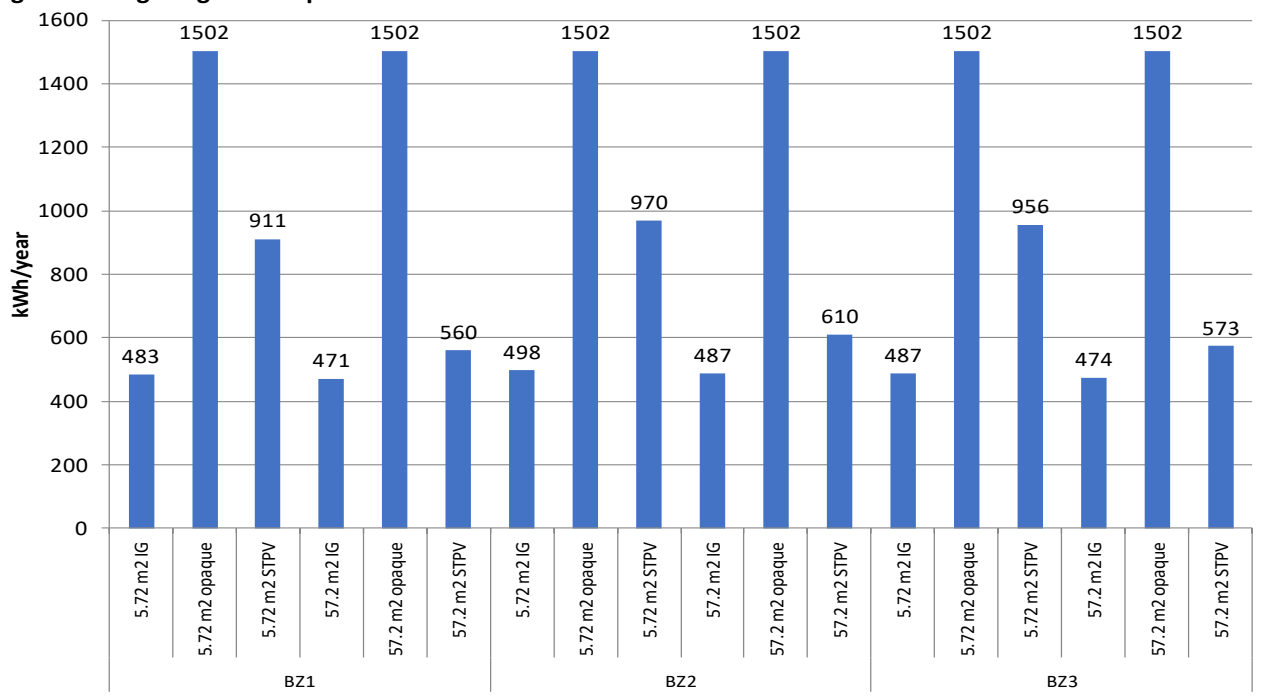

Source: the authors. 
The energy generated by the PV modules was the variable that changed the most among the simulated models, as shown in Figure 12. The opaque models had an estimated production approximately 2.5 times higher than the STPV models if considering the same skylight size and the same bioclimatic zone. This result is consistent with the 2.3 ratio between their maximum efficiency rates, which were $14.24 \%$ for the opaque module (NATIONAL RENEWABLE ENERGY LABORATORY, 2014) and 6.2\% for the STPV glass (WANG et al., 2016). Among the models with a smaller skylight area (4 modules) and larger skylight area (40 modules), for the same PV type and the same bioclimatic zone, the proportion of produced energy was approximately 1:10, as expected ${ }^{(4)}$. The latitude order was preponderant if comparing the bioclimatic zones, since the highest annual production occurred in Curitiba (latitude $25^{\circ} \mathrm{S}$ ) and the lowest in Pelotas (latitude $32^{\circ} \mathrm{S}$ ).

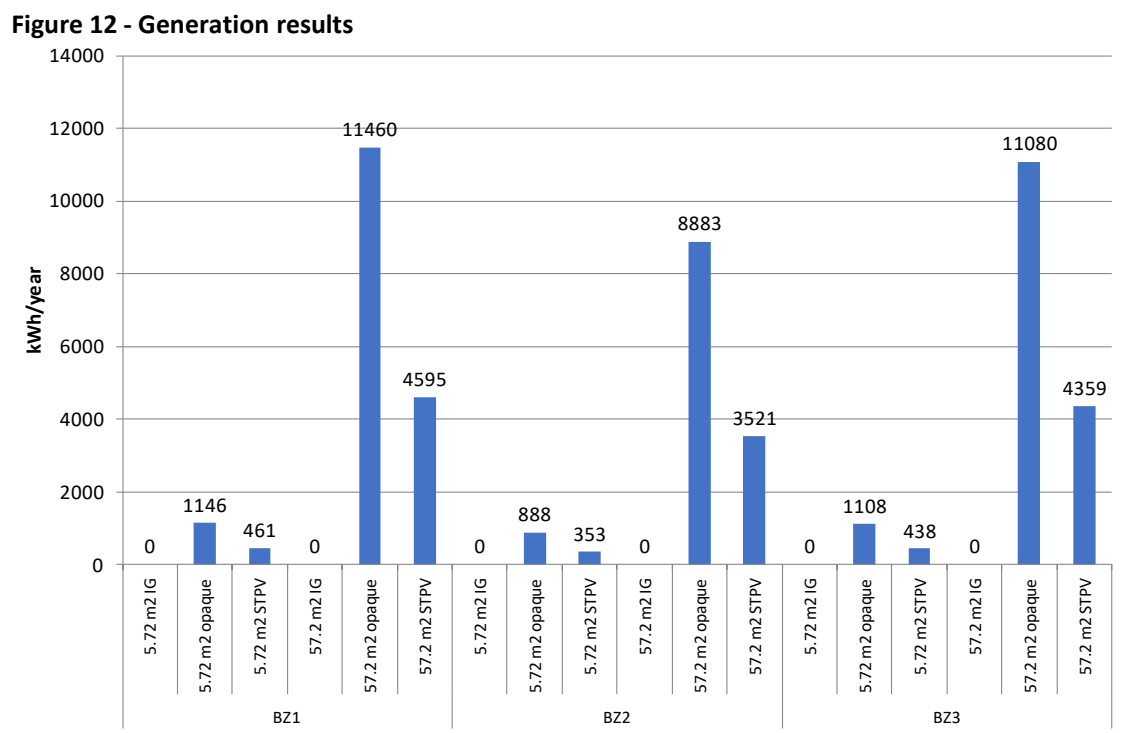

Source: the authors

Figure 13 shows the consumption by end-use, the total consumption, and the generation for all studied models. The total consumption of the STPV models was $28 \%$ smaller on average for all configurations compared to the opaque models.

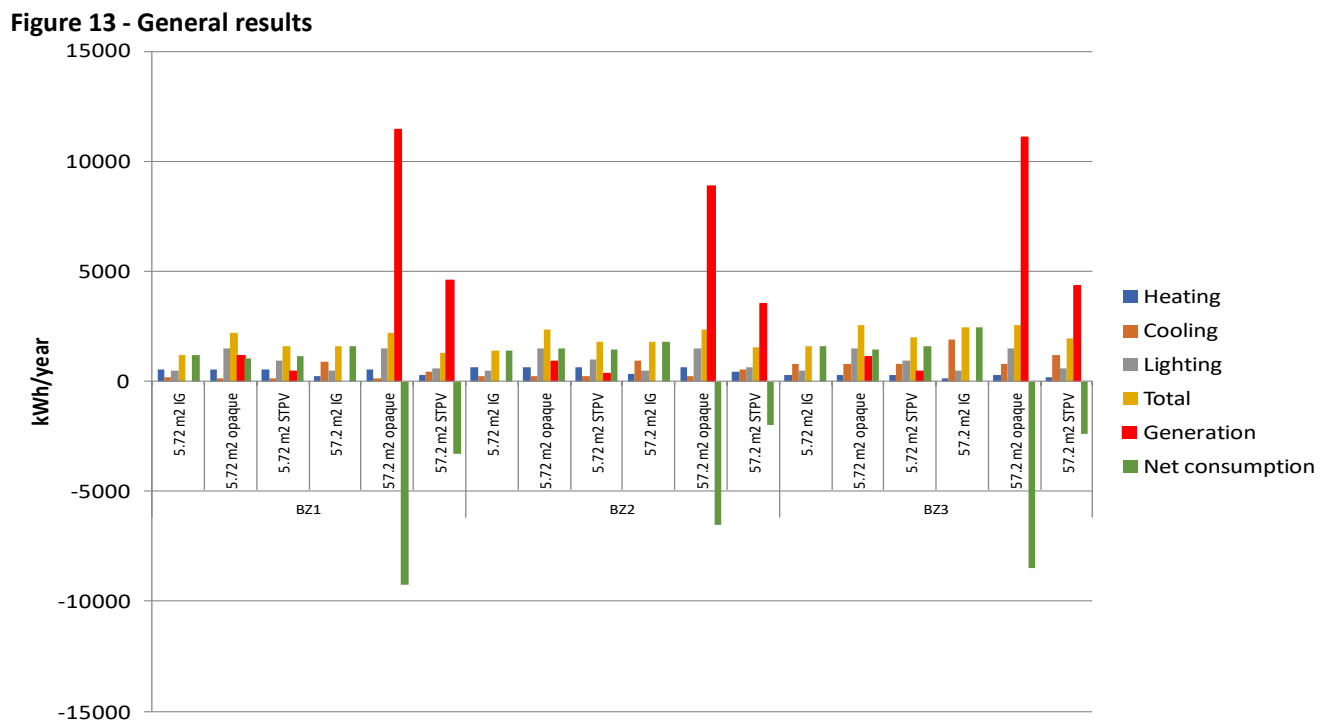

Source: the authors. 
The bioclimatic zone with lower energy consumption - BZ1 - was also the zone with the highest generation, for all studied models, on average $29 \%$ higher than BZ2 and $4 \%$ higher than BZ3. This means that there is an economic benefit in BZ1 compared to the other two zones. In net consumption, which simultaneously indicates the results in generation and consumption, BZ1 presented average values $18 \%$ lower than BZ2 and $30 \%$ lower than BZ3. If comparing the models with larger skylight area, the average in BZ1 was $48 \%$ higher than BZ2 and 15\% higher than BZ3. The advantage exists mainly for the 40-module models because the difference in consumption was much lower than the generation difference. The differences between generation and consumption, shown in Figure 13, and the percentages shown in Figure 14 demonstrate this result. In all bioclimatic zones, the models with larger skylight area produced surplus energy for the whole building. Conversely, the models with smaller skylight area generated insufficient energy to supply the room in which the PVs were applied.

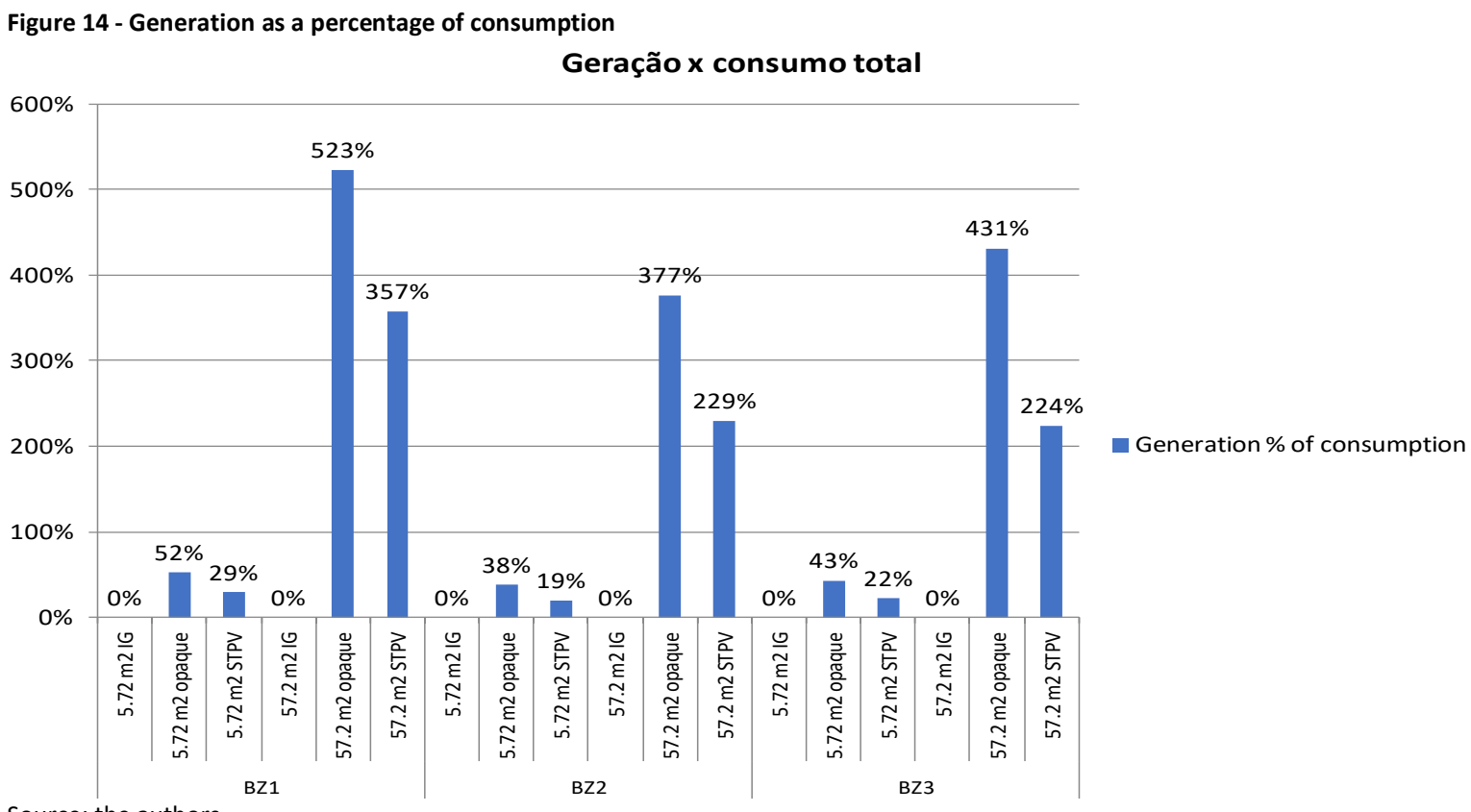

Source: the authors.

\section{Conclusion}

The results of this research work allowed the authors to infer the following conclusions regarding the theme:

- The region considered to be the coldest in the country did not demand more energy for heating.

- The models with skylight had lower consumption with an opaque ceiling due to the relative weight of lighting load and dimming.

- If comparing the STPV glass to the opaque module with the same dimensions, the latter produced more energy, whereas the first consumed less energy. The net balance favoured the opaque modules.

- Considering the analysed models, BZ1 provided a better economic result compared to the other bioclimatic zones studied, especially for the configurations with 40 PV modules, which required the lowest amount of net energy, i.e., purchased from a utility. 
Although the latter statement is true in comparative terms within the scenarios framed in this work, an economic analysis covering the acquisition, installation, and maintenance costs throughout the lifespan of the studied system is necessary in order to reach more comprehensive conclusions on the feasibility of implementing PV generation in semi-transparent glass applied to skylights. Nevertheless, considering only a reduction in energy consumption, the results showed a benefit to the semitransparent glass. Therefore, we conclude that using the technology here investigated has great potential for application in buildings, especially if the conversion efficiency of the STPV modules evolves and gets closer to the opaque modules.

\section{Notes}

(1) Technical quality requirements for energy efficiency in commercial, services. and public buildings, in the Portuguese acronym.

(2) As the roof is composed of homogeneous materials, each layer's parameters were used to configure the simulation, following Brazilian standard NBR 15220 (ASSOCIAÇÃO BRASILEIRA DE NORMAS TÉCNICAS, 2005b).

(3) Ditto.

(4) Disregarding the losses from the inverters, the values would be exactly ten times higher in the 40-module models. The STPV models' ratios showed a greater deviation from the ratio of the number of modules since the lower production made these losses proportionally more significant.

\section{References}

ASSOCIAÇÃO BRASILEIRA DE NORMAS TÉCNICAS. NBR 15220: desempenho térmico de edificações. Parte 3: zoneamento bioclimático brasileiro e diretrizes construtivas para habitações unifamiliares de interesse social. Rio de Janeiro: ABNT, 2005a.

ASSOCIAÇÃO BRASILEIRA DE NORMAS TÉCNICAS. NBR 15220: desempenho térmico de edificações. Parte 2: métodos de cálculo da transmitância térmica, da capacidade térmica, do atraso térmico e do fator solar de elementos e componentes de edificações. Rio de Janeiro: ABNT, 2005b.

ASSOCIAÇÃO BRASILEIRA DE NORMAS TÉCNICAS. NBR 16401: instalações de ar-condicionado: sistemas centrais e unitários. Parte 1: projetos das instalações. Rio de Janeiro: ABNT, 2008 a.

ASSOCIAÇÃO BRASILEIRA DE NORMAS TÉCNICAS. NBR 16401: instalações de ar-condicionado: sistemas centrais e unitários. Parte 2: parâmetros de conforto térmico. Rio de Janeiro: ABNT, 2008b.

ASSOCIAÇÃO BRASILEIRA DE NORMAS TÉCNICAS. NBRISO/CIE8995: iluminação de ambientes de trabalho. Parte 1: interior. Rio de Janeiro: ABNT, 2013.

ASSOCIAÇÃO BRASILEIRA DE NORMAS TÉCNICAS. NBR 7199: vidros na construção civil: projeto, execução e aplicações. Rio de Janeiro: ABNT, 2016.

BERKELEY LAB. OPTICS v.6.o. [S.I.]: LBNL, 2013. Available at: https://windows.lbl.gov/software/optics. Accessed: 9 Sept. 2018.

BERKELEY LAB. WINDOW v7.7.07 IGDB v 68.0.0. [S.I.]: LBNL, 2019. Available at: https://windows.lbl.gov/software/window. Accessed: 1 Aug. 2019.

BIG LADDER SOFTWARE. Euclid. [S.I.: s.n.], 2017. Available at: https://bigladdersoftware.com/projects/euclid. Accessed: 20 Oct. 2018. 
CUSTÓDIO, I. P.; RÜTHER, R. Influência da integração de energia fotovoltaica a uma edificação na sua temperatura interna e no consumo energético da rede elétrica pública. In: ENCONTRO NACIONAL DE CONFORTO NO AMBIENTE CONSTRUÍDO. 14., 2017, Balneário Camboriú. Anais[...]. Balneário Camboriú: ANTAC, 2017.

DIDONÉ, E. L. Parametric study for net zero energy building strategies in Brazil considering semi-transparent PV windows. Karlsuhe, 2014. 212 p. Thesis (Doctor in Engineering) - Department of Architecture, Karlsruhe Institute of Technology, Karlsuhe, Germany, 2014. Available at: https://publikationen.bibliothek.kit.edu/1000044721. Accessed: 14 July 2018.

EMPRESA DE PESQUISA ENERGÉTICA. Balanço Energético Nacional 2019: Ano base 2018. Rio de Janeiro: EPE, 2019. Available at: http://www.epe.gov.br/pt/publicacoes-dados-abertos/publicacoes/balanco-energetico-nacional-2019. Accessed: 22 Dec. 2019.

HANSEN, C. W. et al. Calibration of Photovoltaic Module Performance Models. In: WORLD CONFERENCE ON PHOTOVOLTAIC ENERGY CONVERSION. 6., 2014, Kyoto. Proceedings [...]. Kyoto, Japan: [s.n.], 2014. Available at: https://energy.sandia.gov/wp-content/gallery/uploads/5DV3_56_paper.pdf. Accessed: 9 Sept. 2018.

INSTITUTO BRASILEIRO DE GEOGRAFIA E ESTATÍSTICA. Mapa político do Brasil. [S.I.]: IBGE, 2019. Available at: https://portaldemapas.ibge.gov.br/portal.php\#homepage. Accessed: 2 Aug. 2019.

INSTITUTO NACIONAL DE METROLOGIA, NORMALIZAÇÃO E QUALIDADE INDUSTRIAL. Regulamento Técnico da Qualidade para o Nível de Eficiência Energética de Edificações Residenciais. Rio de Janeiro: INMETRO, 2012. Available at:

http://www.pbeedifica.com.br/sites/default/files/projetos/etiquetagem/residencial/downloads/RTQR.pdf. Accessed: 29 July 2018.

INSTITUTO NACIONAL DE METROLOGIA, NORMALIZAÇÃO E QUALIDADE INDUSTRIAL. Regulamento Técnico da Qualidade para o Nível de Eficiência Energética de Edificações Comerciais, de Serviços e Públicas. Rio de Janeiro: INMETRO, 2013. Available at:

http://www.pbeedifica.com.br/sites/default/files/projetos/etiquetagem/comercial/downloads/Port3722010_RTQ_Def_Edificacoes-C_rev01.pdf. Accessed: 29 July 2018.

JELLE, B. P. Building integrated photovoltaics: a concise description of the current state of the art and possible research pathways. Energies, v. 9, n. 1, p. 1-30, 2016. DOI: https://doi.org/10.3390/en9010021.

KING, D. L.; BOYSON, W. E.; KRATOCHVIL, J. A. Photovoltaic Array Performance Model. Sandia Report $\mathrm{n}^{\circ} 2004-$ 3535, v. 8, n. December, p. 1-19, 2004. DOI: https://doi.org/10.2172/919131.

LABORATÓRIO DE EFICIÊNCIA ENERGÉTICA EM EDIFICAÇÕES. Arquivos climáticos INMET 2012. Florianópolis: UFSC/LabEEE, 2012. Available at: http://www.labeee.ufsc.br/downloads/arquivos-climaticos/formato-epw. Accessed: 9 Sept. 2018.

LI, D. H. W. et al. Energy and cost analysis of semi-transparent photovoltaic in office buildings. Applied Energy, v. 86, n. 5, p. 722-729, 2009. DOI: https://doi.org/10.1016/j.apenergy.2008.08.009.

NATIONAL RENEWABLE ENERGY LABORATORY. Sandia PV module database - library editor of System Advisor Model (SAM). [S.I.]: NREL, 2014.

ORDENES, M. et al. Metodologia utilizada na elaboração da biblioteca de materiais e componentes construtivos brasileiros para simulações no VisualDOE-3.1. Florianópolis: UFSC/LabEEE, 2003. Available at: http://www.labeee.ufsc.br/node/266. Accessed: 9 Sept. 2018.

PENG, J. et al. Validation of the Sandia model with indoor and outdoor measurements for semi-transparent amorphous silicon PV modules. Renewable Energy, v. 80, p. 316-323, 2015. DOI:

https://doi.org/10.1016/j.renene.2015.02.017.

PENG, J. Consult about SAPM parameters. Personal message. Hong Kong, China, 2018. 
DUTRA, L. P.; SALAMONI, I. T.; CUNHA, E. G. da.

Performance simulation of semi-transparent photovoltaic glass on a skylight for commercial building

REN21. Renewables 2019 Global Status Report. Paris: REN21, 2019. Available at: https://www.ren21.net/gsr-2019. Accessed: 5 July 2019.

TRIMBLE NAVIGATION LIMITED. SketchUp Make 2016. [S.I.: s.n.], 2016. Available at: https://www.sketchup.com/download. Accessed: 10 Mar. 2018.

US DEPARTMENT OF ENERGY. EnergyPlus v.9.1.0. [S.I.: s.n.], 2019a. Available at: https://energyplus.net. Accessed: 1 July 2019.

US DEPARTMENT OF ENERGY. EnergyPlus Version 9.1.0 Documentation - Input Output Reference. [S.I.: s.n.], 2019b.

WANG, M. et al. Assessment of energy performance of semi-transparent PV insulating glass units using a validated simulation model. Energy, v. 112, p. 538-548, 2016. DOI: https://doi.org/10.1016/j.energy.2016.06.120.

WONG, P. W. et al. Semi-transparent PV: Thermal performance, power generation, daylight modelling and energy saving potential in a residential application. Renewable Energy, v. 33, n. 5, p. 1024-1036, 2008. DOI: https://doi.org/10.1016/j.renene.2007.06.016.

\footnotetext{
${ }^{1}$ Leno Pôrto Dutra

Engenheiro Eletricista. Mestre em Arquitetura e Urbanismo pela Universidade Federal de Pelotas. Endereço postal: Praça Vinte de Setembro, 121, Pelotas, RS, Brasil, CEP 96.015-360

\section{${ }^{2}$ Isabel Tourinho Salamoni}

Arquiteta e Urbanista. Doutora em Engenharia Civil. Professora do Programa de Pós-graduação em Arquitetura e Urbanismo da Universidade Federal de Pelotas. Endereço postal: Rua Benjamin Constant, 1359, Pelotas, RS, Brasil, CEP 96.010-020

\section{${ }^{3}$ Eduardo Grala da Cunha}

Arquiteto e Urbanista. Doutor em Arquitetura. Professor do Programa de Pós-graduação em Arquitetura e Urbanismo da Universidade Federal de Pelotas. Endereço postal: Rua Benjamin Constant, 1359, Pelotas, RS, Brasil, CEP 96.010-020
} 